\title{
Species diversity and population dynamics of the prevailing land gastropod species on certain crops at Assiut governorate, Egypt
}

\author{
Ibrahim H .A. M. ${ }^{{ }^{*}}$, El-Mesalamy A. F. M. ${ }^{a}$, Baghdadi S. A. S. ${ }^{a}$, Elhanbaly Ruwaida A. A. ${ }^{\text {b }}$ \\ ${ }^{a}$ Agricultural Zoology and Nematology Department, Faculty of Agriculture, Al-Azhar University, Assiut, Egypt \\ ${ }^{b}$ Anatomy and Histology Department, Faculty of Veterinary Medicine, Assiut University, Assiut, Egypt
}

\begin{abstract}
A study was carried out to identify the land gastropod species infesting different host plants and their population dynamics of predominant species at some localities belonging to four districts at Assiut governorate, Egypt. Results revealed that there were five terrestrial snails (Monacha obstructa, Eobania vermiculata, Oxyloma elegans, Cochlicella acuta and Helicodiscus singleyanus inermis) and three slug species (Lehmannia valentiana, Limax flavus and Deroceras leave). These species belonging to seven families of order: Stylommatophora. The snail, M. obstructa was the predominant species, as it was recorded in most of the investigated sites on numerous plants and appeared with high numbers on the majority of vegetable and field crops. Also, C. acuta was recorded for the first time in Sedfa and Assiut districts. Regarding population dynamics, it was found that Egyptian clover infested with high numbers of M. obstructa snails, followed by cabbage and wheat during spring months as compared with winter and autumn months. Accordingly, these results may contribute to designing an appropriate program to control these pests and reduce their damages.
\end{abstract}

Keywords: land gastropods, Monacha obstructa, diversity, population dynamics, Assiut, Egypt. 


\section{Introduction}

Molluscs have been widely distributed over the world. Terrestrial molluscs including snails and slugs belonging to class Gastropoda, are increased greatly in their importance value and became dangerous pests in many parts of the world (Barker, 2002). In Egypt, the terrestrial snails and slugs infesting numerous agronomic, horticulture and ornamental plants causing serious economic damage reduces their yield, quality and marketing values. This damage represented in nibbling the leaves of the plants on which they feed and, in some cases, they bore into other parts as the roots, tubers and fruits (AbdelRahman, 2017; Godan, 1983; Ismail et al., 2003). Besides direct feeding, snails may contaminate plant crops with their bodies, feces and mucous excretions or may transmit plant pathogens like fungi and bacteria (Borkakati et al., 2009; Iglesias et al., 2003). In different sites of Assiut governorate, Egypt, several investigators reported that, these pests have an economic importance for all crops (Abo-Elnaser, 2013; Ibrahim, 2017; Ramzy, 2009). Ecological studies are considered of great importance to obtain some information which useful in designing some suitable methods for controlling terrestrial snails and slugs. This work aimed to study incidence of terrestrial gastropods infesting different host plants and population dynamics of the prevailing land snail, M. obstructa at Assiut governorate, Egypt.

\section{Materials and Methods}

The ecological trials were performed to study the incidence and seasonal population dynamics of some terrestrial gastropods associated with many host plants in some localities at four districts at Assiut Governorate, Egypt which is situated at $\left(27^{\circ} 14^{\prime} \mathrm{N}\right.$ and $\left.31^{\circ} 11^{\prime} \mathrm{E}\right)$. These districts and localities were:

- Assiut district is located in the western of the River Nile and including (Al-Muallimeen (nursery)), Ornamental nursery at Assiut University and Vegetable farm at Assiut University).

- Dirut district is located in the northern of Assiut Governorate and including (Dirut El-Sharif and nursery (Dirut City)).

- El-Fath district is located in the eastern of the River Nile and including (Bossra, Bani Mor (nursery)), Bani Zaid and El-Wasta).

- Sedfa district is in the southern of Assiut Governorate and including (Sedfa (orchard) and Awlad Elias).

\subsection{Occurrence of terrestrial gastropods attacking crops}

Terrestrial snails and slugs were surveyed monthly during the period from March 2018 to February 2020, in the previous mentioned regions. 
The investigated host plants including Field crops were Egyptian clover, wheat, maize and broad bean; Vegetable crops were cabbage, cauliflower, lettuce and onion; Fruit trees were banana, mandarin, naval orange, guava, fig and pomegranate; Ornamental plants were geranium, latania, duranta, paperflower, yucca, ruellia, dusty Miller, kalanchoe and canna. At each sampling site of the investigated areas, five samples were taken randomly in the early morning from each crop by using the quartered sample size $50 \times 50 \mathrm{~cm}$ (Staikou et al., 1990). All snails found on plants, or on soil surface of the sample area were counted, whereas slugs were collected from the surface of the soil or from under the leaf fall and stones or in the detritus or in the grass (South, 1989). The gastropod samples were recorded and transferred in a plastic box to laboratory for examination and identification according to Godan (1983), Genena (2003), Al-Sanabani (2008) and Ramzy (2009).

\subsection{Population dynamics of the prevailing land snails}

The primary incidence studies of terrestrial gastropods at Assiut governorate revealed that Monacha obstructa was the most abundant species in the different study regions. So, the population dynamic of this species was conducted at El-Fath district during two years (2018/2019 and 2019/2020). The land snail, M. obstructa specimens were monthly counted on some field crops (Egyptian clover and wheat) and a vegetable crop was cabbage at El-Fath district, Assiut governorate. Five replicates each of $0.25 \mathrm{~m}^{2}$ were randomly examined from each feddan during the investigated period. Individuals of each land snail species were found on plants, pots and soil surface. The counted snails left in their initial places (Baker, 1988).

\section{Results and Discussion}

3.1 Gastropod species and their incidence on different host plants in certain districts at Assiut governorate, Egypt

The incidence of terrestrial gastropod (snail and slug) species was conducted in different crops during the period of study from March 2018 to February 2020 at some localities belonging to four districts at Assiut governorate, Egypt. Results illustrated in Table (1) showed that, five terrestrial snails and three slug species were found on numerous host plants belonging to seven families of order: stylommatophora. These families and species were: Hygromiidae (Monacha obstructa), Helicidae (Eobania vermiculata), Succineidae (Oxyloma elegans), Geomitridae (Cochlicella acuta, Helicodiscidae (Helicodiscus singleyanus inermis), Limacidae (Lehmannia valentiana and Limax flavus) and Agriolimacidae (Deroceras leave). It is extremely important to 
mention that the conical snail Cochlicella acuta recorded for the first time on Egyptian clover, mandarin, fig, pomegranate, naval orange and guava in Sedfa (orchard), Sedfa districtg and on paperflower and kalanchoe in $\mathrm{Al}$ Muallimeen (nursery), Assiut district, Assiut governorate. Data showed that $M$. obstructa snail was the most prevalent species compared with the other species, where M. obstructa was appeared at the most examined sites on field crops (Egyptian clover, wheat, maize and broad bean); vegetable crops (cabbage, lettuce, cauliflower and onion) and on some ornamental plants (geranium, latania, yucca, ruellia, duranta, dusty Miller and paperflower) in Assiut, Dirut and El-Fath districts at Assiut governorate. On the other hand, $E$. vermiculata and $O$. elegans were detected mainly on ornamental plants. However, the latter was recorded on Egyptian clover, mandarin and naval orange in Bani Zaid, El-Fath district. While the land snail Helicodiscus singleyanus inermis was recorded on ornamental plants in AlMuallimeen (nursery), Assiut district. Concerning the slug species, the slugs Limax flavus and Lehmannia valentiana were observed only in Assiut district on ornamental plants, while $D$. leave was appeared on Egyptian clover, banana and mandarin in El-Fath and Sedfa districts. Also, it was found on some ornamental plants i.e. canna, ruellia and paperflower in the examined district at Assiut governorate. Regarding incidence levels, the glassy clover snail, M. obstructa was recorded with high numbers on many plants such as Egyptian clover, cabbage and lettuce at Dirut and El-Fath districts, and was found with moderate and low numbers on other plants at the same area. At Sedfa district, high numbers of the conical snail, C. acuta was noticed on mandarin, fig, pomegranate, naval orange and guava. To discuss the foregoing results, it was found that many researchers reported that, these pests represent a severe threat to the numerous vegetations all over the world. Also, In Egypt, many terrestrial gastropods recorded in different Governorates have been infesting many important crops. In Sharkia governorate, the field crops (broad bean, clover, wheat, maize and cotton), vegetable crops (eggplant, tomato, pea, cabbage and lettuce) and some fruit trees i.e. mango and orange were attacked by $M$. cartusiana and $S$. putris (Shetaia et al., 2009). In northwestern Egypt, in Alexandria and EL-Beheira governorates; Eshra (2013) observed the presence of five species of land snail at Abees region on grape orchard including Eobania vermiculata, Theba pisana, Helicella vestalis, Monacha obstructa and Oxychillus alliarius; however, at El-Mamoura region, two species of land snail, $E$. vermiculata and $T$. pisana were recorded on ornamental plants in Alexandria Governorate. At Abul-Matamir center, three land snail species including $T$. pisana, $H$. vestalis and $M$. obstructa were recorded on navel orange and apple trees at Kafr El-Dawar center and $E$. 
vermiculata, T. pisana and C. acuta were found on ornamental plants in El-Beheria governorate, Egypt. Gazzy et al. (2018) recorded three species $M$. cantiana, $C$. acuta and T. pisana on Citruc sinesis and Pesidium guava at Kafr El-Sheikh governorate, Egypt. In addition to Aisha (2019) noticed that the glassy clover snail Monacha cartusiana (Müller) and the amber snail, Succinea putris (Linnaeus). M. cartusiana infested all inspected fields of clover, wheat and lettuce in the nine surveyed localities while $S$. putris was detected on clover and wheat in two localities only at Ghrabia governorate, Egypt. Regarding Assiut governorate, Ramzy (2009) observed $M$. obstructa in clover, wheat, naval orange, mandarin, mango, mulberry, geranium, pomegranate and added sugar cane, okra, royal palm and basil.

Table (1): Occurrence and prevalence of terrestrial gastropods on different plants in certain districts at Assiut governorate, Egypt.

\begin{tabular}{|c|c|c|c|}
\hline Districts & Examined Sites & Terrestrial gastropods & Host plants \\
\hline \multirow{3}{*}{ Assiut } & $\begin{array}{l}\text { Al- Muallimeen } \\
\text { (nursery) }\end{array}$ & $\begin{array}{l}\text { Monacha obstructa } \\
\text { Eobania vermiculata } \\
\text { Limax flavus } \\
\text { Cochlicella acuta } \\
\text { Helicodiscus singleyanus inermis }\end{array}$ & $\begin{array}{l}\text { Paperflower (+), Duranta (++) } \\
\text { Yucca }(+), \text { Kalanchoe }(++) \\
\text { Duranta }(+) \\
\text { Kalanchoe }(+), \text { Paperflower }(+) \\
\text { Paperflower }(+++), \text { Yucca }(++)\end{array}$ \\
\hline & $\begin{array}{l}\text { Ornamental nursery } \\
\text { of Assiut University }\end{array}$ & $\begin{array}{l}\text { Monacha obstructa } \\
\text { Eobania vermiculata } \\
\text { Oxyloma elegans } \\
\text { Lehmannia valentiana } \\
\text { Limax flavus } \\
\text { Deroceras laeve }\end{array}$ & $\begin{array}{l}\text { Geranium (++), Latania (++), Yucca (+), Ruellia (++), Duranta(+) } \\
\text { Dusty Miller (+), Canna (+) } \\
\text { Yucca (+), Geranium (++), Paperflower (+), Ruellia (++) } \\
\text { Ruellia (++), Paperflower (++), Geranium (+) } \\
\text { Latania (+), Yucca (+) } \\
\text { Canna (+), Ruellia (+), Paperflower (+) }\end{array}$ \\
\hline & $\begin{array}{l}\text { Vegetable farm of } \\
\text { Assiut University }\end{array}$ & Monacha obstructa & Lettuce (+), Cabbage (+++) \\
\hline \multirow{2}{*}{ Dirut } & Dirut El-Sharif & Monacha obstructa & Egyptian clover (+++), Cabbage (++), Wheat $(+)$ \\
\hline & Nursery (Dirut City) & Monacha obstructa & Dusty Miller (+) \\
\hline \multirow{4}{*}{ El-Fath } & El-Wasta & $\begin{array}{l}\text { Monacha obstructa } \\
\text { Deroceras laeve }\end{array}$ & $\begin{array}{l}\text { E. clover }(+++) \text {, Wheat }(+++) \text {, Cabbage }(+++) \text {, Maize }(+) \text { Onion } \\
(+) \text {, Banana }(+) \text {, Pomegranate }(+) \text {, Lettuce }(+++) \text {, Cauliflower }(++) \\
\text { Egyptian clover }(+) \text {, Banana }(+)\end{array}$ \\
\hline & Bossra & Monacha obstructa & Egyptian clover (+++), Wheat (++), Fig (++), Mandarin (+) \\
\hline & Bani Mor (nursery) & $\begin{array}{l}\text { Monacha obstructa } \\
\text { Eobania vermiculata } \\
\text { Oxyloma elegans } \\
\text { Helicodiscus singleyanus inermis }\end{array}$ & $\begin{array}{l}\text { Duranta }(++) \text {, Paper Flower }(++), \text { Latania }(+) \\
\text { Geranium }(++) \text {, Paperflower }(+) \\
\text { Latania }(+) \\
\text { Duranta }(+)\end{array}$ \\
\hline & Bani Zaid & $\begin{array}{l}\text { Oxyloma elegans } \\
\text { Deroceras laeve }\end{array}$ & $\begin{array}{l}\text { Egyptian clover (+), Mandarin (++), Naval orange (+) } \\
\text { Egyptian clover (+), Mandarin (+) }\end{array}$ \\
\hline \multirow[t]{2}{*}{ Sedfa } & Sedfa (orchard) & $\begin{array}{l}\text { Cochlicella acuta } \\
\text { Deroceras leave }\end{array}$ & $\begin{array}{l}\text { E. clover(++), Mandarin }(+++), \text { Fig }(+++), \text { Pomegranate }(+++), \\
\text { Naval orange }(+++) \text {, Guava }(+++) \\
\text { Egyptian clover }(+)\end{array}$ \\
\hline & Awlad Elias & Monacha obstructa & Broad bean (++), Egyptian clover (++), Mandarin (+) \\
\hline
\end{tabular}

$(+)=$ low numbers $\left(1-15\right.$ individuals $\left./ 0.25 \mathrm{~m}^{2}\right),(++)=$ moderate numbers $\left(15-30\right.$ individuals $\left./ 0.25 \mathrm{~m}^{2}\right),(+++)=$ high numbers (more than 30 individuals $/ 0.25 \mathrm{~m}^{2}$ ).

While, the ornamental plants, oleander, geranium, rubber plant, basil and royal palm, in addition to fruit trees, naval orange, pomegranate, mandarin, mulberry and mango were attacked by $E$. vermiculata. Also, O. elegans was found on the same hosts in addition to, fig, banana, guava and sour orange. AboElnaser (2013) recorded three species of land snails (M. obstructa, E. vermiculata and $O$. elegans) and one species of slugs Limax flavus at Assiut district while, 
Desoky et al. (2015) recorded two species of land snails, M. obstructa and E. vermiculata at Sohag governorate, Egypt as a first record.

\subsection{Population dynamics of Monacha} obstructa on certain field and vegetable crops at El-Fath district

The present data of incidence cleared that, $M$. obstructa was the most widely distributed species on the various host plants. So, the monthly average dynamics of $M$. obstructa snails was studied on certain field crops (i.e. Egyptian clover and wheat) and cabbage as vegetable crop at El-Fath district, Assiut governorate during the period from March 2018 to February 2020 and illustrated in Figures (1 and 2). During the first year 2018/2019, data in Figure (1) revealed that, the highest values of population densities of snail were determined during April 2018 on Egyptian clover and cabbage and during March 2018 on wheat.

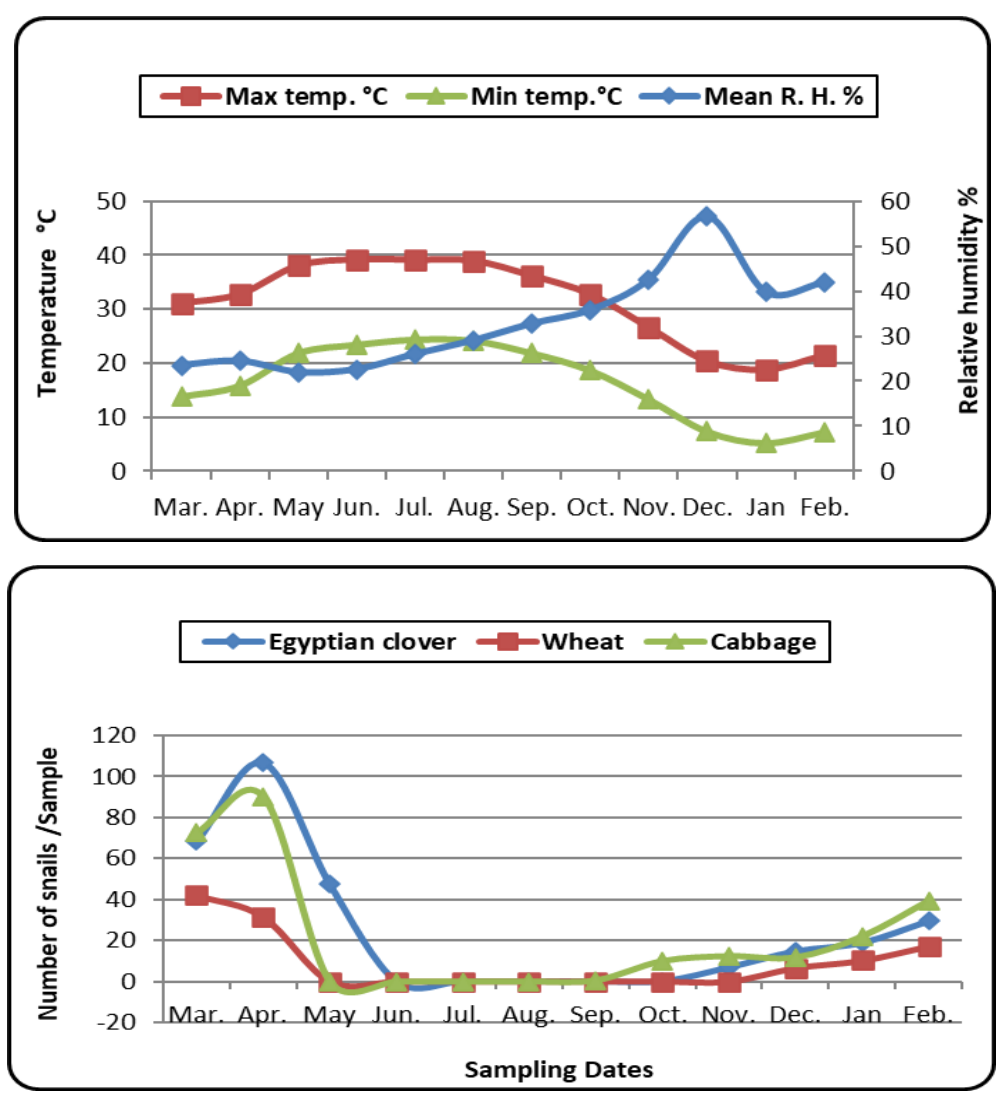

Figure (1): Monthly average numbers of the land snail, Monacha obstructa on certain crops at El-Fath district, Assiut governorate, Egypt during the period from March 2018 to February 2019. 
Numbers of counted snails per sample were $(106.80,90.20$ and 42.20 individuals) respectively. While the lowest infestation of $M$. obstructa were observed during November 2018 on
Egyptian clover and during December 2018 on wheat as well as during September 2018 on cabbage. Numbers of counted snails per sample were $(6.80$, 6.60 and 0.60 individuals) respectively.
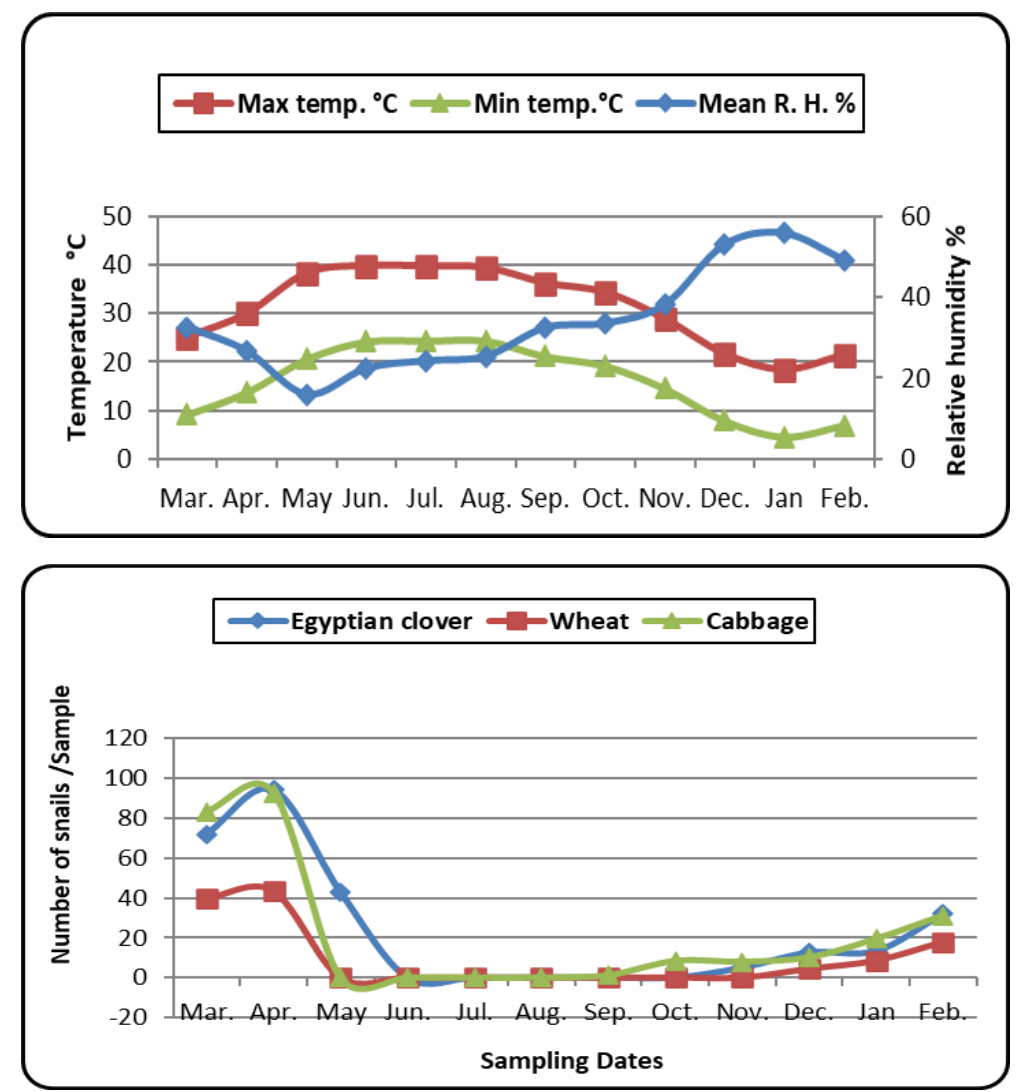

Figure (2): Monthly average numbers of the land snail, Monacha obstructa on certain crops at El-Fath district, Assiut Governorate during the period from March 2019 to February 2020.

Whereas the monthly numbers of $M$. obstructa snail infested Egyptian clover, wheat and cabbage during the second year 2019/2020, data in Figure (2) showed that, the lowest monthly numbers of snail were recorded during November, 2019 on Egyptian clover and during
December, 2019 on wheat also, during September, 2019 on cabbage with (5.00, 4.40 , and 1.20 individuals/sample) respectively, While the highest monthly numbers of snails were determined during April, 2019 on Egyptian clover, wheat and cabbage with $(94.40,43.60$ 
and 92.80 individuals/ sample) respectively. In general, the highest values of population density of $M$. obstructa were recorded during spring months (March and April) as compared to population density during winter and autumn months. Whereas the weather conditions in spring months were suitable for snail activity. Also, the peaks of $M$. obstructa were varied from host plant to another and from month to another. These results were matched with Abd Elkarim (2007) reported that the initial infestation of M. obstructa was recorded in November 2002 on Egyptian clover, guava, navel orange and pear with relatively low population densities. Also, appeared in the beginning of December 2002 with low numbers on wheat and broad bean. Egyptian clover harbored the highest numbers of $M$. obstructa followed by wheat, while broad bean showed the lowest number. In addition to Abo-Elnaser (2013) found that the population density of $M$. obstructa on Egyptian clover was the highest compared to wheat. Hassan (2015) reported that the lowest population of $M$. obstructa was in November on Egyptian clover and in December on broad bean and wheat, while reached to the highest in March number on Egyptian clover and broad bean and in April on wheat. Abou Senna et al. (2016) reported that the land snail, M. cartusiana was more active during March on Egyptian clover and wheat and during February on sugar beet. While the low density was observed during November, December and
February respectively on Egyptian clover, sugar beet and wheat respectively for the two successive growing season 2014-2016 in Sharkia governorate, Egypt.

\subsection{The relationship between population densities of M. obstructa and weather factors}

Results in Table (2) showed that there was a negative correlation between maximum temperature and densities of M. obstructa on cabbage and between minimum temperature and densities on Egyptian clover during 2019/2020, while the population densities of $M$. obstructa were positively correlated with both maximum and minimum temperature on Egyptian clover, cabbage and wheat during 2018/2019. This correlation was insignificant in almost crops except between max. temperature and wheat was significant correlation. On the other hand, there was significant a negative correlation between mean relative humidity and the abundance of $M$. obstructa on E. clover and wheat during 2018/2019 while highly significant a negative correlation with wheat during the second year. Abd El-naser (2013) revealed that there was a positive correlation between numbers of $M$. obstructa and both max. and min. temperature on fruit trees while, it was a negative correlation with highly significant on Egyptian clover during 2010/2011, and with significant during 2011/2012. 
Table (2): Effect of weather factors on population density of M. obstructa on certain vegetable crops.

\begin{tabular}{|l|c|c|c|c|c|c|}
\hline \multirow{2}{*}{ Weather factors } & \multicolumn{2}{|c|}{ Maximum temperature $\left({ }^{\circ} \mathrm{C}\right)$} & \multicolumn{2}{c|}{ Minimum temperature $\left({ }^{\circ} \mathrm{C}\right)$} & \multicolumn{2}{c|}{ Mean R. H. $(\%)$} \\
\cline { 2 - 7 } Host plants & $2018 / 2019$ & $2019 / 2020$ & $2018 / 2019$ & $2019 / 2020$ & $2018 / 2019$ & $2019 / 2020$ \\
\hline Egyptian clover & $-0.643 \mathrm{~ns}$ & $0.358 \mathrm{~ns}$ & $0.517 \mathrm{~ns}$ & $-0.245 \mathrm{~ns}$ & $-0.765 *$ & $-0.618 \mathrm{~ns}$ \\
\hline Wheat & $0.918^{*}$ & $0.878^{*}$ & $0.875 \mathrm{~ns}$ & $0.795 \mathrm{~ns}$ & $-0.912 *$ & $-0.978^{* *}$ \\
\hline Cabbage & $0.176 \mathrm{~ns}$ & $-0.117 \mathrm{~ns}$ & $0.268 \mathrm{~ns}$ & $0.256 \mathrm{~ns}$ & $-0.659 \mathrm{~ns}$ & $-0.454 \mathrm{~ns}$ \\
\hline
\end{tabular}

$\mathrm{ns}=$ correlation is not significant, $*=$ correlation is significant at 0.05 level, $* *=$ correlation is high significant at 0.01 level.

On the other hand, maximum and minimum relative humidity was insignificant negative correlation with numbers of $M$. obstructa on Egyptian clover and wheat during the two years. Abou Senna et al. (2016) showed insignificant positive effect between numbers of $M$. cartusiana and temperature on wheat and Egyptian clover during growing seasons 2015/2016. Also, found insignificant negative correlation on Egyptian clover during 2014/2015 and on sugar beet during 2015/2016. In contrast, highly significant negative effect was observed on sugar beet during season 2014/2015. Insignificant negative correlation was observed on Egyptian clover during growing seasons 2014/2015 and 2015/2016 for sugar beet. While highly significant negative correlation was noticed on Egyptian clover during 2015/2016 and during 2014/2015 for sugar beet. In respect to wheat insignificant positive correlation was noticed during 2014/2015 and significant negative correlation during 2015/2016.

\section{References}

Abd El-Karim Nehmedo (2007), Studies on Life Cycle and Reproduction of Some Snails in Agro-Ecosystems in
North Africa, Ph.D. Thesis, Institute of African Research and Studies, Cairo University, Cairo, Egypt, pp. 148.

Abdel-Rahman Amal H. E. (2017), "Efficiency of some natural plant extracts and ferrous sulphate in controlling the land snail (Monacha cartusiana) under laboratory and field conditions at Sharkia governorate, A.R. Egypt", Journal of Plant Protection and Pathology, Vol. 8 No. 12, pp. 647-650.

Abo-Elnaser, H. A. K. (2013), Ecological and Biological Control Studies on Some Terrestrial Snails and Their Associated Arthropods in Assiut governorate, M.Sc. Thesis, Faculty of Agriculture, Assiut University, Egypt, pp. 94.

Abou Senna, F. M., Almaraghy, A. H. A., Ismail, Sh. A. A. and Abed. M. (2016), "Survey, population dynamics of terrestrial Gastropod infesting certain crops at Sharkia Governorate, Egypt", International Journal of Advanced Research, Vol. 4 No. 11, pp. 641-649.

Aisha Asmaa B. A. (2019), Biological, 
ecological and control studies on certain land snail species infesting certain field and vegetable crops in Gharbia Governorate, M.Sc. Thesis, Faculty of Agriculture, Tanta University, Egypt, pp. 132.

Al-Sanabani, A. S. M. (2008), Biological studies on terrestrial slugs (Gastropoda) in Assiut, Egypt with special reference of their ecology, Ph.D. Thesis, Faculty of Science, Assiut University, Egypt, pp. 174.

Baker, G. H. (1988), "The life history, population dynamics and polymorphism of Cernuella virgata (Mollusca: Helicidae)", Australian Journal of Zoology, Vol. 36 No. 5, pp. 497-512.

Barker, G. M. (2002), Molluscs as crop pests, $\mathrm{CAB}$, International, Walling Forti Oxon 10 DE, UK, pp. 468.

Borkakati, R. N., Gogoi, R. and Borah, B. K. (2009), "Snail: from present perspective to the history of Assam", Asian Agri-History, Vol. 13 No.3, pp. 227-234.

Desoky, A. S. S., Sallam, A. A. and Abd El-Rahman, T. M. M. (2015), "First record of two species from land snails, Monacha obstructa and Eobania vermiculata in Sohag Governorate, Egypt", Direct Research Journal of Agriculture and Food Science, Vol. 3 No. 11, pp. 206-210,

Eshra, E. H. (2013), "Survey and distribution of terrestrial snails in fruit orchards and ornamental plants at Alexandria and EL-Beheira governorates", Journal of Alexandria science exchange, Vol. 34 No. 2, pp. 242-248.

Gazzy Alyaa, A., Mostafa Nadia, M. and Shahawey Wafaa, A. (2018), "Ecological studies on common land snail species Infesting guava and navel orange orchards in two regions at Kafr El-Sheikh Governorate", Journal of Plant Protection and Pathology, Vol. 9 No. 11, pp. 747750.

Genena Marwa, A. (2003), Studies on the terrestrial gastropods at Dakahlia Governorate, M.Sc. Thesis, Faculty of Agriculture, Mansoura University, Egypt, pp. 136.

Godan, D. (1983), Pest slugs and snails, Biology and control, Springer Verlag, Berlin, Heidelberg: New York, USA, pp. 445.

Hassan Eman, K. Kh. (2015), Effect of some environmentally safety biopesticides on some land Molluscs species in Qalubia and Sharkia Governorates, Ph.D. Thesis, Institute of Environmental Studies and Reserch, Ain Shams Univ., pp. 186.

Ibrahim, H. A. M. (2017), Integrated control of terrestrial mollusca at Assiut Governorate, M.Sc. Thesis, Faculty of Agriculture, Al-Azhar University, Cairo, pp. 176.

Iglesias, J., Castillejo, J. and Castro, R. 
(2003), "The effects of repeated applications of the molluscicide metaldehyde and the biocontrol nematode Phasmarhabditis hermaphrodita on molluscs, earthworms, nematodes, acarids and collembolans: a two-year study in north-west Spain", Pest Management Science, Vol. 59 No. 11 , pp. 1217-1224.

Ismail, Sh. A., El-Massry, S. A., Khattab, M. M. and Hassan, A. S. (2003), "Daily activity and damage caused by Eobania vermiculata Müller (Gastropoda: Helicidae) in citrus orchards", Egyptian Journal of Applied Science, Vol. 18 No. 6B, pp.777-785.

Ramzy Remondah, R. (2009), Biological and ecological studies on land snails at Assiut, Egypt, M.Sc. Thesis, Faculty of Science, Assiut University, Egypt, pp. 164.

Shetaia, S. Z. S., Ismail, Sh. A. A. and Abdel-Kader, Samah M. (2009), "Survey, population dynamics and importance value of certain land snail species infesting different crops in Sharkia Governorate, Egyptian Academic Journal of Biological Sciences, Vol. 1 No. 1, pp. 37-43.
South, A. (1989), "A comparison of the life cycles of the slugs Deroceras reticulatum (Müller) and Arion intermedius (Normand) on permanent pastures", Journal of Molluscan Studies, Vol. 55, pp. 922.

Staikou, A., Lazaridou-Dimitriadou M. and Pana, E. (1990), "The life cycle, population dynamics, growth and secondary production of the snail Bradybaena fruticum (Gastropoda: Pulmonata) in Northern Greece", Journal of Molluscan Studies, Vol. 56, pp. 137-146. 